\title{
PHYTOSOCIOLOGICAL ANALYSIS OF ASPEN \\ COMMUNITIES ON THREE SITE CLASSES FOR POPULUS GRANDIDENTATA IN WESTERN CHEBOYGAN COUNTY, MICHIGAN ${ }^{1}$
}

by

\section{W. S. BENNINGHOFF and K. J. CRAMER \\ The University of Michigan}

Stands of Big-tooth aspen (Populus grandidentata MicHx) and Trembling aspen ( $P$. tremuloides Mrchx) in the vicinity of the University of Michigan Biological Station on Douglas Lake, western Cheboygan County, Michigan, have been under study by foresters and plant ecologists since I909 (GATES, 1930; Graham et al., I954; Voss, 1956; Farmer, 1958; Barnes, 1961) (See Fig. I). In this area, $P$. grandidentata attains commercial significance, and three

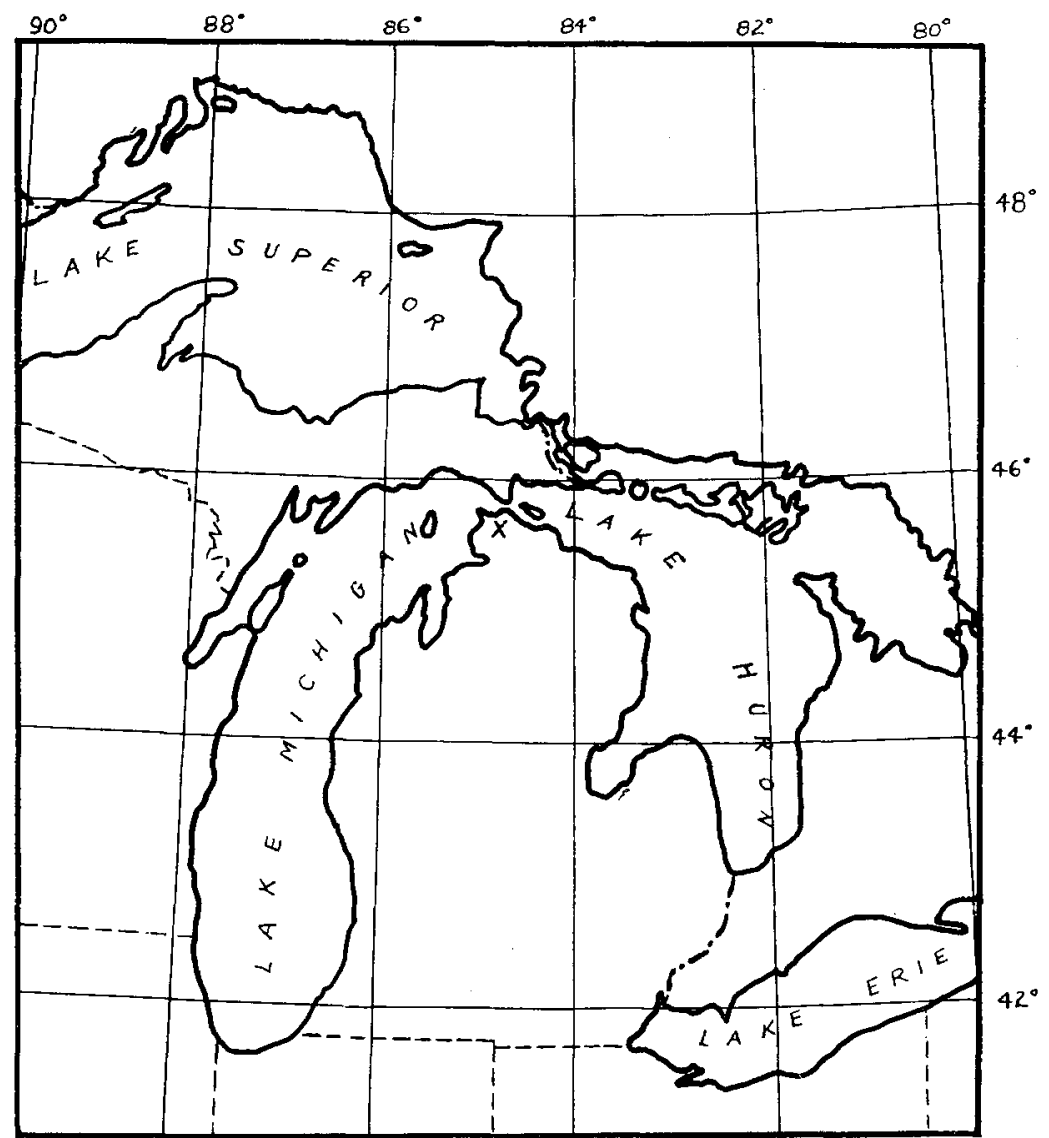

Fig. I. Index map with location of study area marked $X$.

1) This study was aided by research assistance and by related investigations supported by National Science Foundation Grant G-17833, "Phytosociological Survey in Michigan", W. S. BENNINGHOFF, principal investigator. The authors wish to acknowledge guidance in the field and advice on forestry data provided by $D r$. ROBERT ZAHNER, School of Natural Resources, The University of Michigan.

2) Manuscript tecived September 30,1962 . 
classes of sites with respect to its growth potential have been identified (KoENIG, I960). During the summer of I 96 I the relevé method was used to make phytosociological surveys of ten $20 \times 20 \mathrm{~m}$ quadrats in each of the three site classes (Figure 2). We have analysed those data by means of a differential table (Table I). This table demonstrates that each of the three site classes can be distinguished by differential species, within a matrix of characteristic and companion species typical of the aspen communities in the area.

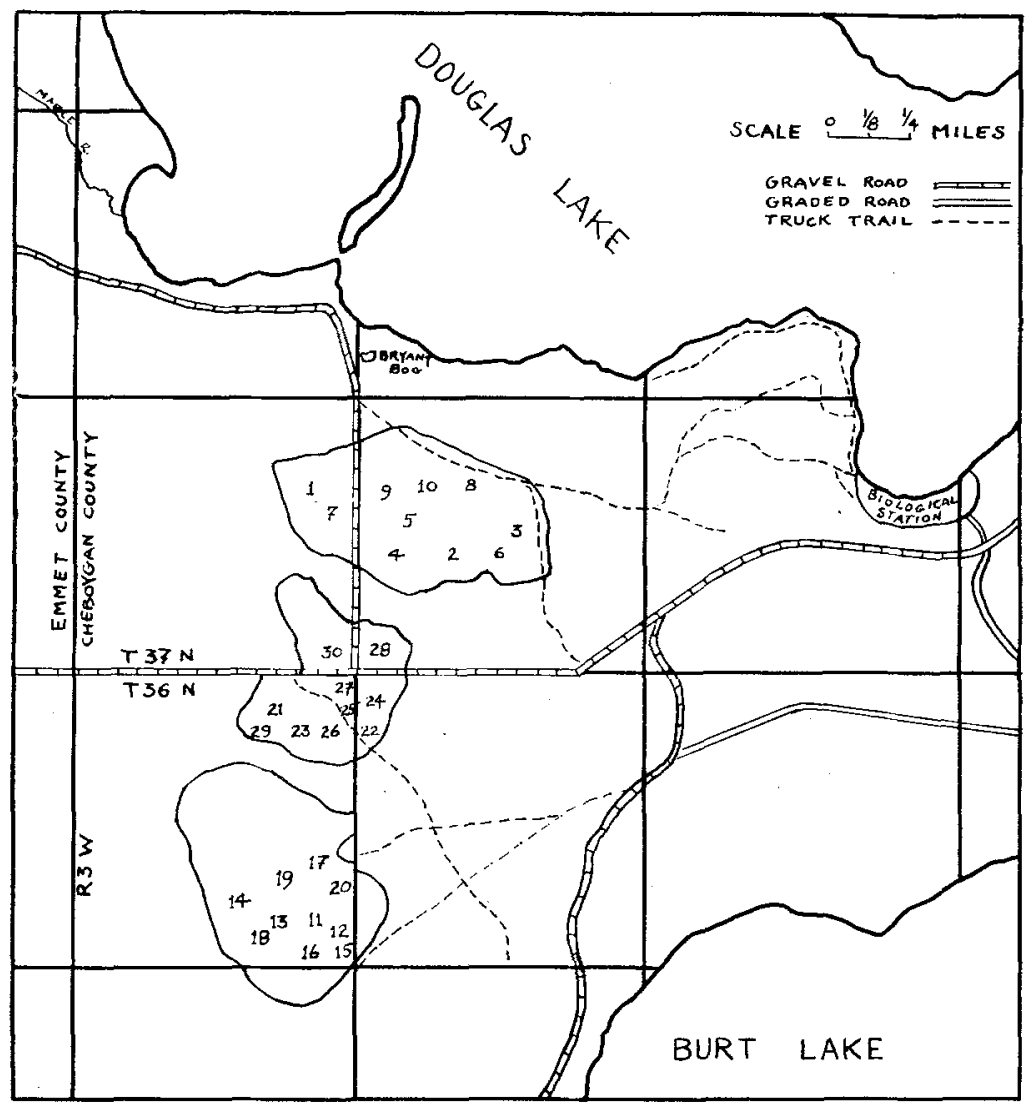

Fig. 2. Sketch map of study area and vicinity, approximately I4 miles south of the Straits of Mackinac, Michigan. Numbers mark locations of sample plots $x$ through 30 . Numbers I through ro are on poor sites for Populus grandidentata growth, I I through 20 are on medium sites, and 21 through 30 are on good sites.

\section{GEOGRAPHIC SETTING}

The study area was confined to a morainic ridge of Valders age (approximately 10,500 years ago) $1 / 2$ to 2 miles southwest of Douglas Lake. The surface is gently rolling, and the maximum difference in altitudes of the sites sampled is $\mathrm{r} 60$ feet $(48.3 \mathrm{~m})$.

In this general area on the uplar.d surfaces the original forest, largely Pinus 
strobus and $P$. resinosa, was clear-cut between 1871 and 1900 . Severe fires swept over most of the area at one time or another between I 880 and 1920 . The most recent fire on the local area occurred in 1923 according to KILBURN (I960), but KoENIG (I960) holds that the last severe fire on the study area proper was in 1918 . In the successional vegetation following the cutting and repeated fires, large clones of both species of aspen developed and dominated the greater part of the landscape. Within the last ten years many of the aspen stands have attained maturity for economic purposes, with trunk diameters (at breast height) of 5 to $\mathrm{I} 2$ inches $(12.5$ to $30.0 \mathrm{~cm}$ ), and heights up to 75 feet $(22.8 \mathrm{~m})$. The present state is probably the optimum development of the aspen communities, and it is expected that they will be succeeded by various stands more similar to the regional climax ,northern hardwoods" forest.

The regional climate, in the Köppen system, is microthermal, humid continental, with cool summers and with precipitation distributed almost equally throughout the year (Dbf climate). The Pellston Plain, immediately west of the moraine where the study was made, is widely known for its strongly continental temperature regime. The diagram of the monthly progression of mean temperatures and mean precipitation shown in Figure 3 is based upon

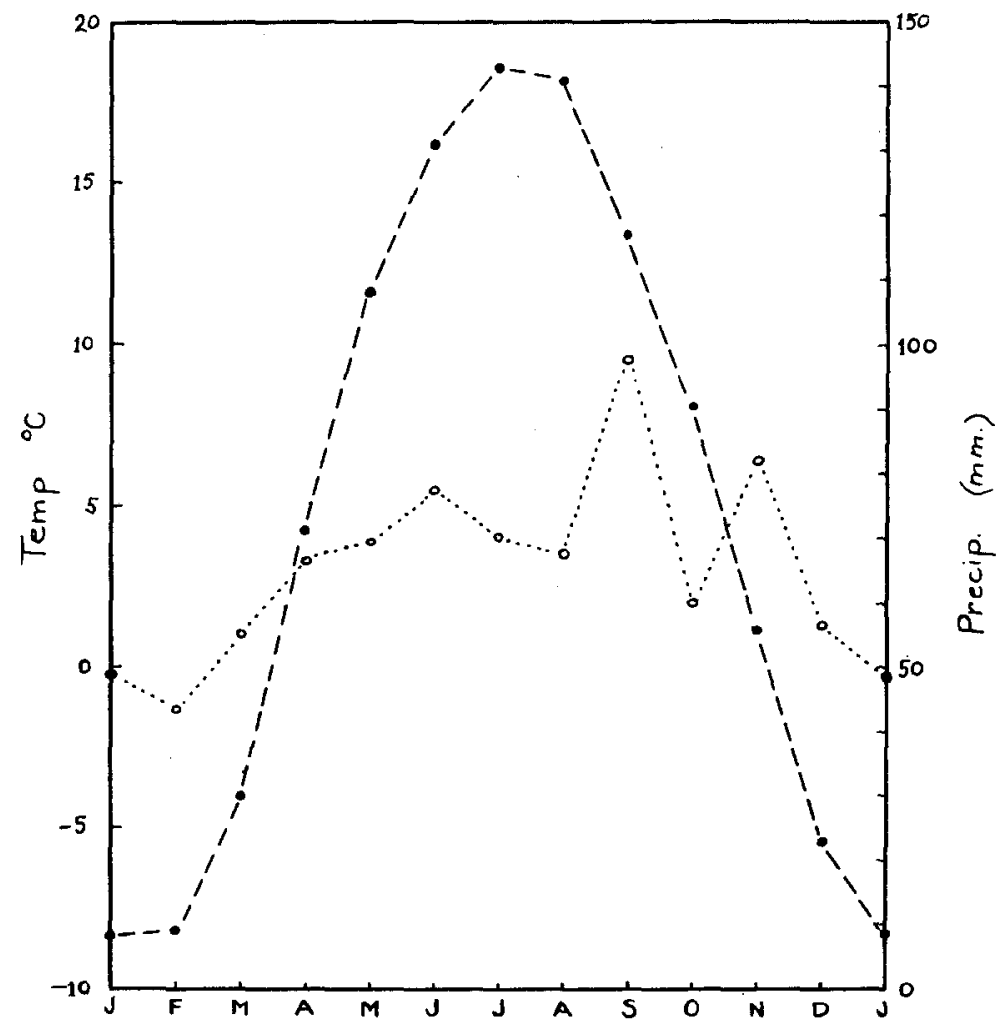

Fig. 3. Graphs of mean monthly temperatures (- - ) and mean monthly precipitation (...) through the year, according to the 19-year record of the nearest metcorological station, Pellston Airport, Emmet Co., Michigan, 7 miles west of the study area. 
the record at the Pellston Airport on this plain (U.S. Dept. Commerce, Weather Bureau, 1942-I96I). Maximum and minimum values on the Pellston Plain may be more extreme than those for the study area.

The soils are distinctive and different for each of the three classes of site (KoENIG, r960; USDA Soil Conservation Service, 1958, 1961a, 196rb). All are podzolized to some degree. Sites of poorest quality are developed on Rubicon sand, a yellow, slightly loamy sand overlying parent material of coarse sand which contains a small amount of pebble-size material. This soil is extremely porous, and the uppermost levels are leached to a light gray color to depths of 3 to 5 inches $(7.5$ to $12.5 \mathrm{~cm})$ beneath a very thin cover of litter and raw humus.

Medium sites are developed on Emmet sandy loam, in which $\mathrm{I}$ to 2 inches $(2.5$ to $5.0 \mathrm{~cm})$ of litter and humus overlie several inches of leached gray sandy loam, in turn overlying a brown sandy loam. This grades downward into a brownish yellow sand over a base of red sandy clay drift containing pockets of gravel, sand, and clay till. The depth to the drift parent material averages about 35 inches $(87.5 \mathrm{~cm})$. Percolation in this soil is impeded by the underlying clay drift, but the levels near the surface are excessively drained.

Sites of good quality are developed on Emmet loamy sand, a podzol developed on sandy glacial drift. Dark-colored forest litter and raw humus form a mat 3 to 6 inches $(7.5$ to $15.0 \mathrm{~cm}$ ) thick, underlain by a gray and locally pale-lavender-colored loamy sand 6 to ro inches ( 15.0 to $25.0 \mathrm{~cm}$ ) thick. At greater depth sand-clay mixtures grade into pale-yellow sand parent material containing pockets of gravel and lenses of red sandy clay drift at various depths. The ground water table in this soil is relatively near the surface most of the year.

\section{METHODS}

Ten relevés, on sample plots each $20 \times 20 \mathrm{~m}$, were taken in each of the three site areas. The sample plots were laid out along arbitrary east-west transect lines within aspen clones intercepted by the transects. No sample plots were closer than $40 \mathrm{~m}$; and clones which showed evidence of recent disturbance (e.g., cutting or experimental work), were not sampled. No more than one sample plot was placed in a single clone, although in several instances a single plot was within the limits of two overlapping clones. Abundance-cover and sociability values (BRAUN-BLANQUET, I95 I) were determined for all species within each plot. Nomenclature of vascular plants follows Gray's Manual, Eighth Edition (Fernald, I950). Dr A. J. Sharp generously assisted the senior author with the identification of many of the Bryophytes and Lichens.

Bitterlich values of basal area were recorded from the center of each quadrat for aspens in the tree stratum; mean and extreme values for each of the three site classes are given below:

\begin{tabular}{l|cc}
\hline \multicolumn{1}{c|}{$\begin{array}{c}\text { Site quality for } \\
P . \text { grandidentata }\end{array}$} & Mean & $\begin{array}{c}\text { Basal area (sq. ft./acre) } \\
\text { Divergence of extreme values }\end{array}$ \\
\hline Poor & 7.9 & $(+3.1,-3.9)$ \\
Medium & 14.5 & $(+5.6,-6.5)$ \\
Good & 13.2 & $(+5.8,-6.2)$ \\
\hline
\end{tabular}




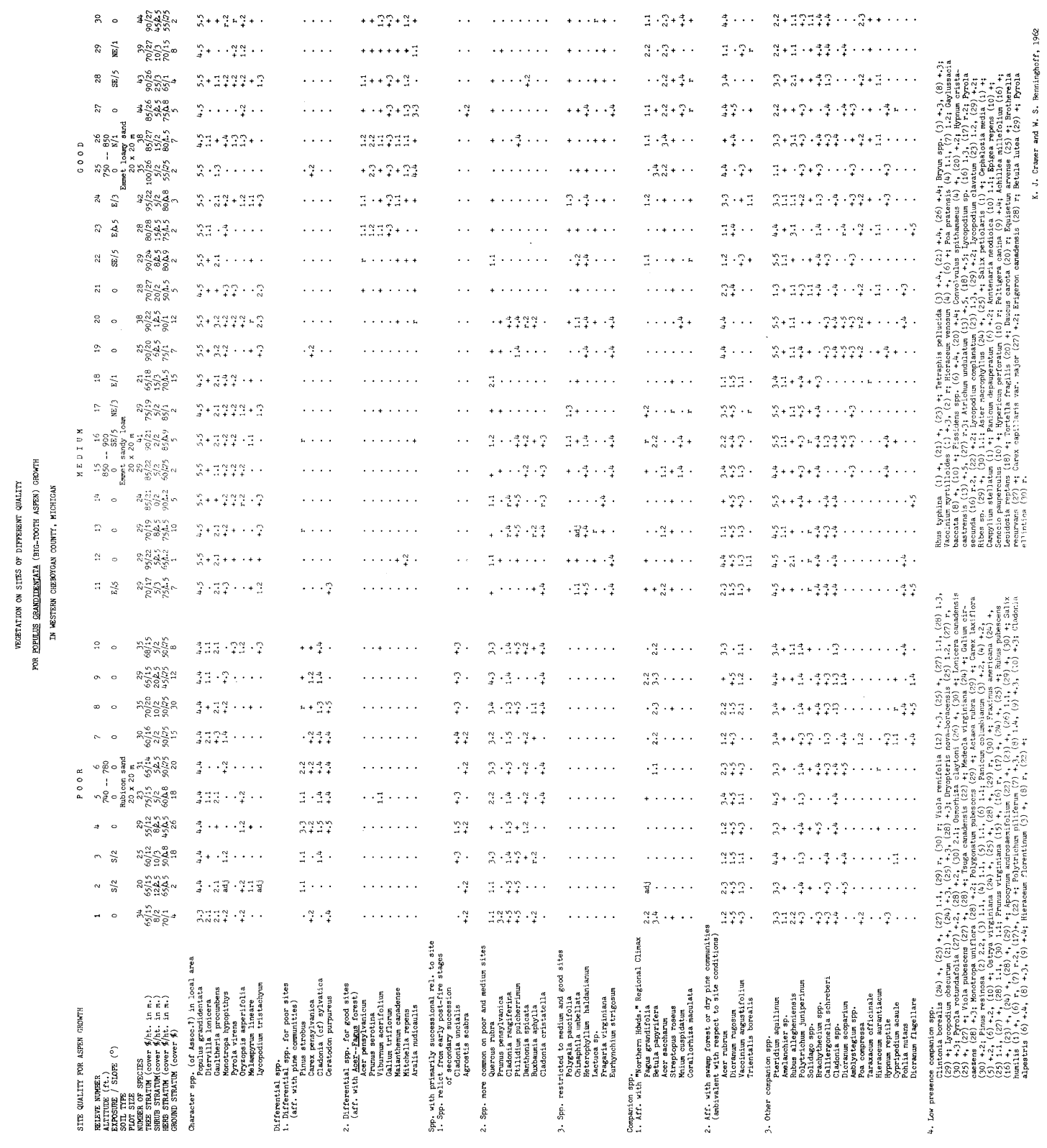


The mean number of trees that could be counted on the good site was less than on the medium site because trees were larger and taller and consequently more widely spaced within these clones. Correlation of Bitterlich values with tree size and height provides a useful check on the site quality as established previously (KoENIG, I960) on the basis of aspen density, merchantability, and clonal growth.

Relevés were compiled in one table ${ }^{1}$ ) in which each of the three site areas was kept as a discrete unit. Species were first ordered according to presence values, and then were rearranged to conform with our interpretations of their fidelity or successional relationships to various other communities in the regional vegetation.

\section{DISCUSSION}

All of the sample plots were within an area of two square miles, and each of the three site classes with its group of differential species is represented by plots clustered in one area of approximately one-quarter square mile. Under these circumstances the similarities and differences in floristic composition might be thought to be entirely the consequences of clustering of the samples in a local area. On the contrary there is very good agreement be tween the species listed in Table $\mathrm{I}$ and the species cited by KITTREDGE (1938) in his thorough study of the habitat and associated species relationships to aspen growth rate in Minnesota and Wisconsin. Both $P$. grandidentata and $P$. tremuloides participate as dominants, either separately or together, with no discernible difference in the composition of the lower: strata. $P$. tremuloides clones of widely deffferent sizes occur in the general area of this study, but our sample plots were positioned with special reference to $P$. grandidentata clones. BARNES (I96I) determined that $\mathrm{I}$ to $5 \%$ of the clones in the Lower Peninsula of Michigan are hybrids between the two species of aspens.

The concept of fidelity was applied to the grouping of species in Table I, insofar as our knowledge of the habitat and community affinities of the various species permitted. The character species for the aspen community in the local area were selected for the reason that, at least within the Douglas Lake region, they not only exhibit high constancy but are either exclusive in this association or are found to attain in this association their best expressions with respect to life cycles and population size. Within the study area the $P$. gradidentata stands have sufficient phytosociological unity on three relatively different site types to warrant postulation of an association, the Populetum tremuloido-grandidentatae. We believe that this association eventually will be identified throughout the greater part of the range of $P$. grandidentata, although knowledge of the frdelity of associated species is as yet inadequate to permit certainty in the selection of character species, even within the local study area.

Although we believe they may eventually be found suitable for characterization of a formally defined association the character species are here treated as local character species. The present list may possibly include some that may prove to be local in northern Lower Michigan, e.g. Lycopodium tristacbyum. On the other hand, species shown here as companions, such as

1) Table $I$ is a folded insert in this issue.

Vegetatio, XI, 5-6. 
Vaccinium angustifolium, Dicranum rugosum, Polytricbum juniperinum, and Calliergonella scbreberi, possibly will prove to be character species, but certainly of lower fidelity, as they occut prominently in one or more other associations as well.

DANSEREAU (1959), in his floristic characterization of Laurentian Lowland plant associations by dominant species in the several layers or synusiae, defined the Populetum tremuloidis as follows:

\begin{tabular}{|c|c|c|}
\hline Layer & Cover & Species \\
\hline 6 & Continuous & $\begin{array}{l}\text { Populus tremuloides } \\
\text { Populus grandidentala }\end{array}$ \\
\hline 5 & very sparse & Prunus virginiana \\
\hline 4 & $\begin{array}{l}\text { discontinuous } \\
\text { to continuous }\end{array}$ & Pteridium aquilinum \\
\hline 3 & in patches & Aster macrophyllus \\
\hline 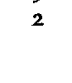 & $\begin{array}{l}\text { intertupted } \\
\text { of in patches }\end{array}$ & $\begin{array}{l}\text { Maianthemum canadense } \\
\text { Trientalis borealis } \\
\text { Lvcopodium obscurum }\end{array}$ \\
\hline $2^{\prime}$ & continuous & Lycopodium flabelliforme \\
\hline $\mathrm{I}$ & in patches & $\begin{array}{l}\text { Polytrichum ohioense } \\
\text { Dicratnum scoparium }\end{array}$ \\
\hline
\end{tabular}

Aster macropbyllus, Maiantbemum canadense, Trientalis borealis, and Lycopodium obscurum are common in the northern hardwoods deciduous forest (primarily Acer, Fagus, Betula, and Tsuga) of northern Lower Michigan; and in this study these species were found mainly on the good sites.

GraNDTNER (1960), in his survey of a forest area southwest of the City of Quebec, described three Populus tremuloides communities on podzols. In these, 17 of 44 species are in common with our communities in western Cheboygan County. He places his aspen communities within the Populetum tremuloidis of Dansereau although his table includes only Pteridium aquilinum, Maiantbemum canadense, and Polytricbum obioense of DaNSEReau's nine character species of the understory; he does, however, list some related species that may be serving as substitutes, e.g. Prunus pensylvanica, Lycopodium annotinum, $L$. clavatum, and Dicranum undulatum. It is evident that neither DANSEREAU nor GRANDTNER encountered aspen communities of the kind represented on the poor sites in western Cheboygan County.

In Table $\mathbf{I}$ the poor and good site classes are clearly distinguishable by exclusive differential species. The medium site class is distinguished by the lack of such differential species.

The ,Differential species for poor sites" are species common in Pinus strobus and $P$. resinosa communities of the region, and undoubtedly they are here as the vanguard of the succeeding community. $P$. resinosa, although exclusively on poor sites in Table I, cannot be considered a differential species, as many of these trees were planted in the $1930^{\circ} \mathrm{s}$, and there is little natural reproduction (Table 2 ). Consequently $P$. resinosa is listed with the „Low presence companion species."

The „Differential species for good sites” are species that are likely to prove to be character species for the maple-beech forest (in many respects comparable to the Aceretum sacchari Fagetosum of the Laurentian Lowland (Dansereat, 1959)). Thus these species probably represent advance members of the maple-beech forest that will succeed the existing aspen 
Table 2. Frequency percentages and importance value indices for trees and shrubs in separate strata (tree, shrub, and herb) in the three site classes for Populus grandidentata growth. The importance value index (IVI) was calculated by summing the abundance-cover estimates as follows: $r=0,+=I, I=5,2=15,3=40,4=60,5=80$. Relative reproduction and maturity of the several species is indicated in the table.

\begin{tabular}{|c|c|c|c|c|}
\hline & & POOR & MEDIUM & GOOD \\
\hline & & $\mathrm{F} \%$ IVI & $\mathrm{F} \%$ IVI & $\mathrm{F} \% \quad$ IVI \\
\hline \multirow[t]{3}{*}{ Populus grandidentata } & $\mathrm{T}$ & $100-580$ & $100-720$ & $100-720$ \\
\hline & $\mathrm{S}$ & $20-2$ & $30-3$ & - \\
\hline & $\mathrm{H}$ & $20-2$ & $20-I$ & - \\
\hline \multirow[t]{3}{*}{ Pinus strobus } & $\mathrm{T}$ & $40-6 x$ & - & - \\
\hline & $\mathbf{S}$ & Io- $I$ & - & - \\
\hline & $\mathrm{H}$ & $60-17$ & $20-0$ & 一 \\
\hline \multirow[t]{3}{*}{ Acer pensylvanicum } & $\mathrm{T}$ & - & - & $30-7$ \\
\hline & $\mathrm{S}$ & - & 一 & $60-I_{4}$ \\
\hline & $\underset{\mathrm{T}}{\mathrm{H}}$ & 一 & 一 & $90-8$ \\
\hline \multirow{2}{*}{ Prunus serotina } & $\mathrm{s}$ & - & 二 & $40-36$ \\
\hline & $\mathrm{H}$ & - & 二 & $\begin{array}{ll}20- & 2 \\
10- & I\end{array}$ \\
\hline \multirow{2}{*}{ Viburnum acerifolium } & $\mathrm{S}$ & $20-\mathrm{I}$ & - & $70-\mathrm{II}$ \\
\hline & $\mathrm{H}$ & ro- 6 & IOC I & $80-20$ \\
\hline \multirow[t]{3}{*}{ Quercus rubra } & $\mathbf{T}$ & $80-235$ & $30-15$ & - \\
\hline & $\mathrm{S}$ & $30-7$ & I0- 5 & IOL $\mathrm{I}$ \\
\hline & $\mathrm{H}$ & $100-54$ & $90-13$ & 70 - II \\
\hline \multirow{3}{*}{ Prunus pensylvanica } & $\mathrm{T}$ & $10-15$ & $30-\mathrm{I}$ & - \\
\hline & $\mathrm{S}$ & IO- I & $40-4$ & IO- I \\
\hline & $\mathrm{H}$ & $10-I$ & IO- I & - \\
\hline \multirow[t]{3}{*}{ Fagus grandifolia } & $\mathrm{T}$ & $20-$ ro & IO- I & $60-36$ \\
\hline & $\mathrm{S}$ & $20-10$ & 10 - I & ro- $x$ \\
\hline & $\mathrm{H}$ & IO- I & $40-3$ & $30-3$ \\
\hline \multirow[t]{3}{*}{ Betula papyrifera } & $\mathrm{T}$ & $60-130$ & $20-16$ & $10-40$ \\
\hline & $\mathrm{S}$ & IO- I5 & - & 一 \\
\hline & $\mathrm{H}$ & IO- 0 & - & I0- I \\
\hline \multirow[t]{3}{*}{ Acer saccharum } & $\mathbf{T}$ & - & $30-25$ & $50-100$ \\
\hline & $\mathrm{S}$ & 一 & - & $20-16$ \\
\hline & $\mathrm{H}$ & - & $20-2$ & $70-\mathrm{II}$ \\
\hline \multirow[t]{3}{*}{ Acer rubrum } & $\mathrm{T}$ & $80-145$ & $80-182$ & $70-185$ \\
\hline & $\mathrm{S}$ & IO- I & $30-2 \mathrm{~T}$ & $70-31$ \\
\hline & $\mathrm{H}$ & $90-13$ & $100-62$ & $100-52$ \\
\hline \multirow[t]{3}{*}{ Amelanchier sp. } & $\mathrm{T}$ & - & - & I0- I \\
\hline & $\mathrm{S}$ & $30 \div 7$ & $50-9$ & $90-13$ \\
\hline & $\mathrm{H}$ & $90-9$ & $90-2 I$ & $90-9$ \\
\hline \multirow[t]{2}{*}{ Tsuga canadensis } & $\mathrm{S}$ & - & - & IO- I \\
\hline & $\mathrm{H}$ & - & - & ro- $I$ \\
\hline \multirow[t]{3}{*}{ Pinus resinosa } & $\mathrm{T}$ & $40-30$ & 一 & 一 \\
\hline & $\mathrm{S}$ & $40-4$ & 一 & 一 \\
\hline & $\mathrm{H}$ & 10- 5 & 一 & - \\
\hline \multirow[t]{2}{*}{ Ostrya virginiana } & $\mathbf{T}$ & - & - & ro- $s$ \\
\hline & $\mathrm{S}$ & 一 & - & 10- 5 \\
\hline \multirow{2}{*}{ Fraxinus americana } & $\begin{array}{l}\mathrm{H} \\
\mathrm{S}\end{array}$ & 二 & - & $50-4$ \\
\hline & $\mathrm{H}$ & 一 & - & $40-4$ \\
\hline \multirow{2}{*}{ Prunus virginiana } & $\mathrm{S}$ & - & IO- I & -4 \\
\hline & $\mathrm{H}$ & - & $20-\mathrm{I}$ & $20-2$ \\
\hline \multirow{2}{*}{ Salix humilis } & $\mathrm{S}$ & ro- 0 & IO- I & ro- I \\
\hline & $\mathrm{H}$ & $20-I$ & - & - \\
\hline Betula lutea & $\mathrm{S}$ & 一 & - & ro- I \\
\hline
\end{tabular}


forest. These species appear to be relatively reliable indicators of the good site for aspen, but possibly are not identifiable as a group until the aspen stand on such a site has become almost mature.

KI'TTREDGE (1938) found that individual species are not sufficiently explicit as indicators of site index for aspen. He concluded that natural community plant indicator groups and soil profile groups serve relatively well for prediction of aspen growth potential on the sites he investigated. Our results embodied in Table I lead us to similar conclusions.

Although the aspen communities under consideration here areacknowledged to be only seral stages within the regional climax forest, they are regenerated in the landscape as a consequence of disturbance, primarily by fire. An aspen community persists on a given site until vegetational succession replaces it with a forest community that more nearly approaches the most stable vegetation the site will support. In Table I some species are grouped according to their probable successional relationships. The group "Species relict from early post-fire stages of secondary succession" is composed of species known to be aggressive on open, disturbed sites of various kinds and observed to be pioneers on plots experimentally burned by F. C. GATES and others (FARMER, 1958). It is not surprising that these pioneers should persist as relics longer on the sites of poor quality on the drought-subject Rubicon sand soil; and it would be appropriate to consider these as differential species for identifying poor sites.

F. C. Gates followed the progressive development of the aspen stands in the vicinity of Douglas Lake more than 30 years. In 1930 he described the aspen association of the area. He also pointed out that on the sandy upland soils the aspen becomes dominated by pines (or with an intermediate stage of Quercus borealis (Q. rubra)) after 30 to 40 years; on low, wet ground it becomes dominated by Thuja after 12 to 20 years or by Picea-Abies, or by Fraxinus-Ulmus; and on the ,better" soils it becomes beech-maple forest in 20 to 25 yers. Now, after the opportunity to observe these stands 30 years after GATEs' paper, we would multiply his time estimates by a factor of 2 or 3, but would affirm his view of the direction of succession. Gates' (I930) desctiption of the aspen association (which he termed a ,,secondary association") may be summarized by the following annotated list:

General appearance:

Higher shrub stratum

Bracken fern stratum

Diervilla stratum

Ground stratum

Consocies of Prumus pensylvanica

Subdominant species:

Pteridium aquilinum

Diervilla lonicera (locally in almost pure patches)

Associated species: (approximate frequency, * is more than $10 \%, 0$ is $6-10 \%$ )

Acer rubrum *

A. spicatum o

Apocynum androsaemifolium o Aralia nudicaulis *
I to $2 \mathrm{~m}$.

0.5 to $0.8 \mathrm{~m}$.

slightly less than $0.5 \mathrm{~m}$.

of herbaceous or somewhat woody plants, including grasses, or patches of Cladonia or Polytrichum.

occurs locally

Equisetum sylvaticum *

Fragaria virginiana o

Galium triflorum o

Gaultheria procumbens * 


Aster laevis o
Betula papyrifera
Botrychium virginianum o
Comandra umbellata o
Cornus canadensis 0
Diervilla lonicera *
Epilobium angustifolium *
Equisetum arvense o
Rumex acetosella (considered to be
the most aggressive early invader)

\author{
Hieraceum scabrum o \\ Lactuca canadensis * \\ Melampyrum lineare * \\ Mosses and lichens o \\ Rubus allegheniensis \\ Rubus triflorus \\ (= R. pubescens) \\ Solidago canadensis
}

It is interesting to compare the above list with Table I. In place of Acer spicatum we found only $A$. pensy'vanicum, although both are known to occur in the local area. We did not find Equisetum sylvaticum, Epilobium angustifolium, Botrychium virginianum, Comandra umbellata, or Cornus canadensis, all of which now occur locally in the aspen stands, especially on sites adjacent to Douglas Lake and the Biological Station grounds. Rather than Hieracium scabrum, we found only $H$. florentinum and $H$. venosum var. tonsum; and instead of Aster leavis, we found only $A$. macropbyllus. Most of these differences in the two lists are probably owing to changes in composition that attend development from the early to the mature stage in the aspen community history.

The "Species more common on poor and medium sites" are probably invaders of succeeding pine-oak communities, or oak savanna or pine savanna communities, all of which may be of only seral status. The "Species restricted to medium and good sites" include some species that are associated with pine communities (e.g. Chimapbila umbellata) or with open deciduous woods communities (eg. Fragaria virginiana). Where the species in these two groups occur together, they serve to characterize the medium sites.

Among the companions, a group of six species is distinghished as those having "Affinities with Northern Hardwoods Regional Climax" for want of more precise categories into which they might be placed. Although Fagus grandifolia, Betula papyrifera, Acer saccharum, and Tsuga canadensis are character species of the maple-beech forest in this region, there remains doubt as to their fidelity for that association or subassociation. Similarly others in this group have as yet undetermined fidelity for various associations. However, all in this group are plants of mesic sites, and can be considered as character species for the regional climax.

The group of species having ,Affinities with swamp forest or dry pine communities" contains an assemblage of more or less ambivalent species with respect to their occurrence in wet or dry habitats. Notable among these are Acer rubrum, Dicranum rugosum, and Vaccinium augustifolium. Trientalis borealis occurs primarily on moist or wet habitats, but with relatively wide amplitude.

We believe that the differential groups indentified from this very local study area do have applicability over a much wider area for the identification of site classes for $P$. grandidentata growth potential and as indicators of the probable direction of succession on sites now occupied by aspen. The groups of species with primarily successional relationships serve as additional indicators of the directions and progress of succession. Tests of these species groups are needed, of course, to determine the areal extent of their validity as indicator species. Such tests will also improve our concepts of the species fidelity for various associations. 


\section{CONCLUSIONS}

From the results of the above-described study, we draw the following conclusions :

I. Within the study area, site quality for $P$. grandidentata growth is reflected by differential species, some of which are relict from earlier stages of succession, others of which are invaders leading to succeeding communities that will occupy the different site types. Tests of these differential species in adjacent and more distant localities will determine the areal extent of their usefulness.

2. The sites of poor quality for aspen growth are progressing toward Pinus resinosa- $P$. strobus forest and Quercus rubra-Pinus forest. The good sites ate developing toward Acer-Fagus forest stands. The medium sites have potentialities for development of either the pine communities or the maplebeech community. On these sites perhaps subtle differences in soils, historical sequences with respect to propagule availability, or short-term trends in the local climate may determine which of the several possible forest communities will succeed the aspen. However, Table I suggests that the medium site class is not truly intermediate between the poor and good classes but has greater potential for development in the direction of the Acer-Fagus forest.

\section{SUMMARY}

Ten $20 \times 20 \mathrm{~m}$ plots were surveyed in each of three site classes (poor, medium, and good) for Populus grandidentata growth on three different podzolized soils in western Cheboygan County, Michigan, 14 miles south of the Straits of Mackinac. A phytosociological table shows that exclusive differential species distinguish communities of the poor sites from those of the good sites. In both groups some species are persistent from earlier stages of succession and others are invading species responsible for more recent succes sional change. The medium site class lacks differential species. Poor-site stands are developing toward Pinus resinosa-P. strobus forest and Quercus rubra-Pinus forest. Good-site stands are developing toward Acer-Fagus forest, a mesophytic community characteristic of the "northern hardwoods" regional climax. Medium-site stands have potentialities for development toward either the Pinus communities or the Acer-Fagus community, but predominantly in the direction of the latter.

\section{ZUSAMMENFASSUNG}

Zehn Aufnahmen von jeder Standortsklasse (arm, mittel, gut) hinsichtlich des Wachstums von Populus grandidentata auf drei verschiedenen podsolierten Böden in West Cheboygan County, Michigan, I4 Meilen südlich der Mackinacstrasse werden vorgelegt. Eine phytosoziologische Tabelle erweist, dass die ausschliesslichen Differentialarten die Pflanzengesellschaften der armen Standorte von jenen der guten unterscheiden. Einige Arten der beiden Gruppen haben sich aus früheren Sukzesșionsstufen erhalten, während einige andere als Eindringlinge aufzufassen sind. Der Mittelstandortsklasse fehlen die Differentialarten. Die Pflanzengesellschaften der armen Standortsklasse entwickeln sich zum Pinus resinosa-P. strobus-Wald und zum Quercus 
rubra-Wald, Gesellschaften der guten Standortsklasse zum Acer-Fagus-Wald einer mesophytischen Gesellschaft, die für den ,nördlichen Laubwald” den Regionalklimax darstellt. Mediumstandortsbestände können sich entweder zu den Pinus-Gesellschaften oder aber zu der Acer-F agus-Gesellschaft (meistens zu letzterer) entwickeln.

\section{RÉSUMÉ}

Dix relevés de $20 \times 20 \mathrm{~m}$. Ont été faits dans chacune des trois catégories (pauvre, moyenne et bonne) de sites de rapportant à la croissance de Populus grandidentata sur trois soils podsolizés dans la partie occidentale du Comté de Cheboygan (Michigan), I4 miles au Sud du Détroit de Mackinac.

Le tableau phytosociologique montre que les espèces diffétentielles exclusives distinguent nettement la végétation des sites pauvres de celle des bons sites. Dans les deux groupes, quelques espèces des étapes de l'évolution précédente se maintiennent tandis que d'autres s'installent, ébauchant une évolution ultérieure. La végétation des sites moyens ne possède pas $d^{\prime}$ espèces différentielles. La végétation des sites pauvres se développe vers la forêt de Pinus resinosa - P. strobus et la forêt de Quercus rubra-Pinus. La végétation des bons sites se développe vers la forêt d'Acer-Fagus, association caractéristique du climax regional (,,northern hardwoods”). La végétation des sites moyens se développe soit vers les associations de Pinus ou plus souvent vers l'association d'Acer-Fagus.

\section{LITERATURE CITED}

Barnes, Burton, V., x959 - Natural variation and clonal development of Populus tremuloides and P. grandidentata in Northern Lower Michigan. Unpublished Ph. D. thesis, University of Michigan Library, Ann Arbor.

-, I961 - Hybrid aspens in the Lower Peninsula of Michigan. Rhodora 63: 311-324.

Braun-Blanquet, J., I95 I — Pflanzensoziologie. Springer Verlag: Wien.

Dansereat, Pierre, I959 - Phytogeographia Laurentiana. II The principal plant associations of the Saint Lawrence Valley. Contrib. Inst. Bot. Univ. Montreal, No 75, 147 pp.

EllenberG, H., I956 - Aufgaben und Methoden der Vegetationskunde. In Grundlagen der Vegetationsgliederung, Bd. IV of Einführung in die Phytologie, hgb. von HEINRICH WALTER. Stuttgart: EUGEN ULMER.

FARMER, ROBERT, E., JR., 1958 - Some effects of prescribed burning following clear-cutting in poor site aspen. Master's thesis, Department of Forestry, University of Michigan, Ann Arbor (unpublished).

Fernald, M. L., I950 - Gray's Manual of Botany, 8th ed., New York: American Book Co.

GATES, Frank, C., I930-Aspen association in Northern Lower Michigan. Bot. Gaz. 90 : 233-259.

Graham, S. A., C. E. Westelt, Jr. \& R. P. Harrison, I954. A study of the aspens in the Lower Peninsula of Michigan. Pboenix Memorial Project No. 29, I 27 pp. typescript, illus. (unpublished progress report).

Grandtner, Miroslav, M., ig60 - La Forêt de Beauséjour, Comte de Lévis, Quebec: Étude Phytosociologique. Laval University Forest Research Foundation (Quebec), Contribution No. 7, 62 pp.

Killburn, Paul, D., I960 - Effect of settlement on the vegetation of the University of Michigan Biological Station. Pap. Micbigan Acad. Sci., Arts, \& Ltrs. 45: 77-8I.

KITtredGe, JoSEPH, JR., I938 - The interrelationships of habitat, growth rate, and associated vegetation in the aspen community of Minnesota and Wisconsin. Ecol. Mon. 8: $r 5 r-246$.

KOENIG, RoBERT, L., I960 - Variation in tree size and quality of naturally occurring Big. 
tooth Aspen clones in Northern Lower Michigan. Master's thesis, Department of Forestry, University of Michigan, Ann Arbor. (unpublished).

U.S. Department of Agriculture, Soil Conservation Service. r96ra. Productive potential of soils for wood crops, Michigan, Lower Peninsula. Micbigan Soil Conservation Service Woodland Tech. Note No. I6, 6 pp., mimeographed.

-, $196 \mathrm{Ib}$. National Cooperative Soil Survey in Michigan: Emmet Series. 2 pp., mimeographed. -, I958. National Cooperative Soil Survey in Michigan: Rubicon Series. 2 pp., mimeographed.

U.S. Department of Commerce, Weather Bureau. I942-1961. Climatological Data, State of Michigan. Vol. 57-76.

Voss, E. G., I956-A history of floristics in the Douglas Lake region (Emmet and Cheboygan Counties), Michigan, with an account of rejected records. J. Sci. Labs., Denison Univ. 44: $16-75$. 